\title{
BMJ Open Disciplinary complaints concerning transgressive behaviour by healthcare professionals: an analysis of 5 years jurisprudence in the Netherlands
}

\author{
Frank L Gerritse (D) , ${ }^{1}$ Robbert J Duvivier (D) ${ }^{2,3}$
}

To cite: Gerritse FL, Duvivier RJ. Disciplinary complaints concerning transgressive behaviour by healthcare professionals: an analysis of 5 years jurisprudence in the Netherlands. BMJ Open 2021;11:e053401. doi:10.1136/ bmjopen-2021-053401

- Prepublication history for this paper is available online. To view these files, please visit the journal online (http://dx.doi. org/10.1136/bmjopen-2021053401).

Received 12 May 2021 Accepted 17 September 2021

Check for updates

(C) Author(s) (or their employer(s)) 2021. Re-use permitted under CC BY-NC. No commercial re-use. See rights and permissions. Published by BMJ.

${ }^{1}$ Psychiatry, Tergooi Hospitals, Hilversum, The Netherlands

${ }^{2}$ Centre for Education

Development and Research in Health Professions (CEDAR),

University Medical Centre

Groningen, Groningen, The

Netherlands

${ }^{3}$ Parnassia Academy, The Hague, The Netherlands

Correspondence to

Dr Robbert J Duvivier;

r.j.duvivier@umcg.nl

\section{ABSTRACT}

Objectives To study the frequency of observed cases of disciplinary law complaints concerning transgressive behaviour in Dutch healthcare by analysing disciplinary cases handled in Dutch disciplinary law.

Design Retrospective review of complaints in the Dutch disciplinary law tribunals from the period 1 January 2015 to 1 January 2020.

Setting Dutch healthcare.

Method Descriptive retrospective study. All judgements at regional disciplinary tribunals in the first instance from the period 1 January 2015 to 1 January 2020 concerning transgressive behaviour were investigated. The following was studied: year of judgement, number and nature of complaints, type of complainants, profession of defendant. Results Over the study period, 139 complaints about transgressive behaviour were handled, 90 of which involved sexual behaviour. 66/139 complaints were submitted by patients themselves (47.5\%). Most complaints were directed against physicians (44.6\%; $\mathrm{n}=62)$, followed by nurses $(30.2 \%$; $n=42)$, psychologists (11.5\%; $n=16)$ and physiotherapists $(7.9 \% ; n=11)$. $80.6 \%$ of the complaints were directed against a male healthcare professional (OR 4.25; 95\% $\mathrm{Cl} 1.7590$ to 10.2685; $p=0.0013$ ). $104 / 139$ of the complaints originated from an outpatient work setting and about half of the complaints originated from mental healthcare. Of the 90 disciplinary cases in which the complaint was related to sexually transgressive behaviour, $83.3 \%(n=75)$ were ruled to be substantiated ( 5 of which partially) with a measure imposed in all cases: 6 formal warnings (8\%), 11 reprimands (14.7\%), 10 denials (partial suspension) (13.3\%), 26 temporary suspensions (34.7\%) and 22 cancellations of the licence to practice $(29.3 \%)$. Conclusion This study describes jurisprudence of disciplinary cases about transgressive behaviour of healthcare professionals in the Netherlands. The results of this study can be used to monitor trends in observed cases of transgressive behaviour.

\section{INTRODUCTION}

Patients are in a vulnerable position during contact with healthcare professionals, as they are directly dependent on them for receiving care. Patients must be able to rely on their healthcare providers not to abuse this trust.

\section{Strengths and limitations of this study}

- This study uses primary source data: anonymised, publicly available jurisprudence from the Dutch disciplinary law tribunals.

- This study is limited by the inherent limitations of the website of the Dutch disciplinary law tribunals.

- This study is limited to healthcare professionals that are registered under article 3 of the Dutch Healthcare Professionals Act.

- This study is limited to numerical analysis: no conclusive explanatory insights or hypotheses can be generated with this.

Indeed, most medical students swear some kind of oath or declaration, on entry to medical school or at graduation, as an explicit commitment to ethical behaviour. ${ }^{1-3}$ In fact, the Hippocratic Oath expressly denounces boundary transgressions, such as sexual transgressive behaviour. 'Into whatsoever houses I enter, I will enter to help the sick, and I will abstain from all intentional wrong-doing and harm, especially from abusing the bodies of man or woman, bond or free. ${ }^{4}$

Despite such oaths, promises and intentions, transgressive behaviour occurs within healthcare. In this paper, the focus is on behaviours by healthcare workers that have adverse interpersonal consequences or violate the patient-professional relationship or trust. Such boundary violations come in many varieties. Sexual transgressive behaviour consists of any form of behaviour that is sexual of nature and violates boundaries of the victim, either mental or physical. This includes having a sexual relationship, performing sexual acts, assault or sending sexually explicit messages or comments.

The scarcity of literature on the subject of misconduct in healthcare possibly indicates a possible underestimation of the magnitude of the problem. In recent years, more attention 
has been paid to sexually transgressive behaviour in society such as the \#MeToo movement. ${ }^{5}$ It is possible that this has influenced both healthcare providers and patients: on the one hand by sharper boundaries, on the other hand by a lower threshold for reporting unacceptable behaviour.

Against this background, we examined disciplinary actions taken against healthcare providers for either professional or sexual misconduct. This includes any behaviour that causes physical, mental or emotional damage to patients. ${ }^{6}$ Despite the immorality of these actions, previous research ${ }^{8}$ found that about $0.1 \%$ of all licensed US physicians had been subject to disciplinary action for sexual misconduct, approximately 9.5 per 10 000 physicians every 10 years. In comparison, a similar study from Canada ${ }^{9}$ found disciplinary action for 15.5 per 10000 physicians per 10 years; 1.6 times higher than in the USA. This difference likely reflects faster detection of transgressive behaviour in Canada; there is no evidence to suggest that Canadian doctors are more susceptible to sexually transgressive behaviour than their American counterparts. Perhaps the litigious culture in the USA plays a role in this. Seen in that light, the question is to what extent available literature can be extrapolated to other countries, with different litigation and different procedures for complaints and disciplinary action. Emerging literature about transgressions by other healthcare providers, such as nurses and physiotherapists, provides additional insight into the scope of these issues. For example, a survey among Australian physiotherapists found that respondents were aware of a colleague who had dated a patient (33\%) or ex-patient $(60 \%) \cdot{ }^{10}$ A Swiss study on sexual contacts between nurses and patients in psychiatric hospitals found that $17 \%$ of male and $11 \%$ of female respondents reported having had such contact, which $94 \%$ of respondents considered 'inappropriate'. ${ }^{11}$

To add to the scant literature on this topic, in this study, we aimed to provide insight into (sexually) transgressive behaviour by analysing disciplinary cases handled in Dutch disciplinary courts. Our objective was to study frequency of observed cases, content and outcome of disciplinary law complaints concerning transgressive behaviour against Dutch healthcare professionals.

\section{METHODS}

This study used publicly available information about disciplinary law cases in the Netherlands. We will outline the context first, before providing details on the data collection and analysis.

\section{Context of Dutch disciplinary law}

The system of disciplinary law differs from country to country. In the Netherlands, disciplinary law for physicians was introduced in 1928, and updated in 1993 to also include other healthcare professionals under the Healthcare Professionals Act (Dutch: Wet BIG). ${ }^{12}$ The goal of Dutch disciplinary law is (1) to guard and improve the quality of healthcare, (2) to protect patients from incompetent and careless behaviour, and (3) to enhance public trust in the medical profession. ${ }^{13}{ }^{14}$ It differs from civil law in that complainants can not file for financial compensation and the disciplinary tribunals cannot impose prison sentences or other penal punishments.

Two other systems for dealing with patient complaints exist in the Netherlands. All hospitals and healthcare practices are obligated to have an internal system for patients to file complaints. Another option for patients is to file a claim at the civil court. For the purpose of this study, we focus on complaints handled by the Dutch disciplinary tribunals.

In principle, any 'directly interested party or stakeholder' can file a complaint against any individual healthcare provider. In practice, this stakeholder often is a patient, their partner or close relative. ${ }^{15-17}$ An employer or healthcare institution can also file a complaint, as can the Health \& Youth Care Inspectorate (IGJ) ${ }^{18}$ and health insurance companies. The IGJ is a Dutch institution, part of the Ministry of Health, that supervises public health in the Netherlands.

All complaints are handled by one of the five regional disciplinary tribunals (RDTs; Amsterdam, The Hague, Eindhoven, Groningen and Zwolle). After an RDT decision has been made, both the complainant and the defendant can appeal to a central disciplinary tribunal for healthcare (CDT).

The tribunal reviews complaints according to standards set out in Dutch law: the goal is to determine if there was any act or omission directed at a patient that went contrary to what is considered appropriate by the medical profession. On receipt of a complaint, the tribunal determines whether the complaint meets the requirements (eg, justified stakeholder). A copy of the complaint is sent to the defendant with a request for a written response, and the complainant can file a second statement in reply. The disciplinary tribunal can ask for additional information from, for example, other healthcare workers involved in the case or relevant experts. After this phase of information gathering, the tribunal calls for a private hearing between both parties. This hearing is not mandatory, and is intended as mediation to seek a resolution between plaintiff and defendant. If the case remains unresolved, it moves to the tribunal for full review of the written statements. The tribunal can either find the complaint inadmissible and reject it at this point, or move it to public hearing. A rejection is always accompanied by a motivated report. Both parties and their legal representation are invited to the public hearing. There is opportunity to provide further information and if parties or the tribunal want to hear external experts or witnesses, they are also heard. Based on the public hearing, the tribunal provides a written judgement which is published anonymously online on a dedicated government website: https:// tuchtrechtoverheidnl. The complete process from complaint to decision, takes between 9 and 12 months. ${ }^{19}$ If the complaint is substantiated and the healthcare 
professional is found to be at fault, a number of disciplinary measures can be imposed: the range includes a formal warning or reprimand, to a fine (paid to the state) or a suspension (temporary or permanent) from practice. No patients were involved in the design or conduct of this study.

\section{Study design and sample}

This investigation was carried out in June-September 2020. We used the public website https://tuchtrecht.overheid.nl, which contains all the rulings of disciplinary cases handled by the tribunals. Rulings contain a summary of the complaint, often with verbatim examples, and a summary of the complainant and defendant's point of view, with an annotated discussion of the legal considerations and final verdict. We collected all published complaints as handled by the regional tribunals between 1 January 2015 and 1 January 2020 by means of a systematic keyword search on the Dutch word 'grensoverschrijdend', which means 'transgressive'. For the sake of completeness, we have not limited ourselves to the category 'transgressive behaviour' assigned by the tribunals, but searched and analysed the full text of all rulings. This resulted in 265 rulings, 81 of which were ruled by the CDT and 184 by the RDT. For this study, we disregarded the complaints in appeal, that is, handled by the CDT, because of the time delay in which cases are assessed at the CDT ( $>1$ year after submission). We then read all cases and excluded all cases where the complaint was not about unacceptable behaviour of the care provider (37 cases were excluded because it involved transgressive behaviour of the patient; 147 cases remained). Inclusion criteria were: (1) complaint against health professional, (2) complaint about transgressive behaviour from health professional. We classified these disciplinary cases on the basis of the year of decision, nature of the complaint (eg, sexual misconduct or professional misconduct), type of complainant (patient, family, employer, healthcare inspection), decision and treatment setting (clinical, ambulatory, independent, etc). This showed that in eight cases the respondent was both a registered psychiatrist/psychologist/doctor and a psychotherapist, so that two statements about the same complaint were included. We have combined these cases as 'psychiatrist/psychotherapist' and 'psychologist/ psychotherapist', respectively. This left 139 unique cases for further analysis. Because of limitations in the registration of medical specialists in used website, we could not differentiate between child and adult psychiatrists. We report both filed (ie, unsubstantiated) and substantiated cases in this paper as the reason why complaints are filed in itself is worthy of study, and follows methodology used in similar studies in other countries.

\section{Statistical analysis}

Statistical analyses were performed using R (V.3.6) 11. We used descriptive statistics, ORs and $\mathrm{X}^{2}$ where appropriate. For all analyses (all tests two sided), a $\mathrm{p}<0.05$ was considered statistically significant.

\section{Patient and public involvement}

No patients were involved in the design or conduct of this study.

\section{RESULTS}

\section{Number of handled complaints}

In the period 2015-2019, the five RDTs handled 5116 complaints in total, 139 (2.7\%) of which concerned transgressive behaviour by healthcare professionals, on average 27.8 per year.

\section{Type of misconduct}

$64.7 \%(90 / 139)$ of the substantiated complaints concerned sexual transgressive behaviour. In the other 49 substantiated cases the transgressive behaviour was of non-sexual nature. Examples include intimidation, theft (using the patients bank card to obtain money), or fraud (falsification of medication prescriptions).

\section{Defendant profession}

The most complaints were made against physicians ( $44.6 \% ; \mathrm{n}=62)$, followed by nurses $(30.2 \%$; $\mathrm{n}=42)$, psychologists $(11.5 \% ; n=16)$, physiotherapists $(7.9 \% ; n=11)$ and other healthcare providers (table 1). Within the group of physicians, the largest group consisted of psychiatrists and general practitioners (respectively, $\mathrm{n}=21$ and $\mathrm{n}=19$; $33.8 \%$ and $30.6 \%)$, followed by medical residents $(16.1 \%$; $\mathrm{n}=10)$. Of the nurses, one out of five worked as a nurse in the field of psychiatry (19\%; n=8). In 2020, there were 72 834 registered physicians, 194325 nurses, 16079 psychologists and 4986 psychotherapists in the Netherlands. ${ }^{20}$ When corrected against these numbers of registered professionals, this means over the 5 -year period of the study, complaints were made against respectively $0.085 \%$, $0.022 \%, 0.10 \%$ and $0.22 \%$ of physicians, nurses, psychologists and psychotherapists.

\section{Defendant work setting}

$74.8 \%$ ( $\mathrm{n}=104)$ of the complaints concerned defendants in an outpatient treatment setting (including general practice, physiotherapy, dentist office, home care), followed by hospital/in patient/clinic (18.0\%; n=25). Forensic settings and private situations (eg, ex-lovers or family of the defendant) each accounted for five complaints (both 3.6\%). The outpatient setting can be further divided into outpatient of a mental health institution or hospital $(76 \%)$, self-employed physician (private practice) $(17.3 \%)$ and home care $(2.9 \%)$ and sheltered housing (2.2\%). Of the 139 complaints of transgressive behaviour, $51.8 \%(\mathrm{n}=72)$ came from mental healthcare. This is comparable for sexually transgressive behaviour: $52.2 \%(n=47)$ comes from mental healthcare. Statistically speaking, filed complaints of sexually transgressive behaviour do not occur more often in the group of mental healthcare professionals, compared with the group of care providers outside of mental healthcare (OR $1.05 ; 95 \%$ CI 0.523 to $2.11 ; \mathrm{p}=0.892$ ). 
Table 1 The number of handled complaints regarding misconduct/transgressive behaviour, per year and defendant profession

\begin{tabular}{|c|c|c|c|c|c|c|}
\hline \multirow[b]{2}{*}{ Defendant } & \multicolumn{5}{|l|}{ Year } & \multirow[b]{2}{*}{ Total } \\
\hline & 2019 & 2018 & 2017 & 2016 & 2015 & \\
\hline Cosmetic physician & & 1 & & & & 1 \\
\hline Dentist & & 2 & 2 & & 1 & 5 \\
\hline District nurse & 1 & & & & & 1 \\
\hline General practitioner & 5 & 3 & 6 & 3 & 2 & 19 \\
\hline Gynaecologist & & & 1 & 1 & & 2 \\
\hline Gynaecology resident & & & 1 & & & 1 \\
\hline Insurance physician & & & 1 & & & 1 \\
\hline MD (not specialised) & 1 & 1 & 3 & & 4 & 9 \\
\hline MD/psychologist & & & 1 & & & 1 \\
\hline Mental healthcare worker & & & 1 & & & 1 \\
\hline Nurse & 10 & 7 & 5 & 5 & 6 & 33 \\
\hline Occupational physician & & 2 & 1 & & & 3 \\
\hline Orthodontist & & & 1 & & & 1 \\
\hline Paediatrician & & & 1 & & & 1 \\
\hline Pharmacist & & 1 & & & & 1 \\
\hline Physiotherapist & 4 & 1 & 4 & 1 & 1 & 11 \\
\hline Plastic surgeon & & & 1 & & & 1 \\
\hline Psychiatrist & 4 & 1 & 3 & 2 & 3 & 13 \\
\hline Psychiatrist/psychotherapist & 2 & 1 & 2 & & 3 & 8 \\
\hline Psychologist & 1 & 1 & 4 & 3 & 1 & 10 \\
\hline Psychologist/psychotherapist & & 1 & 2 & & 2 & 5 \\
\hline Psychotherapist & 1 & & & & & 1 \\
\hline Rheumatology resident & & & & & 1 & 1 \\
\hline Social psychiatric nurse & 1 & 2 & 2 & 1 & 2 & 8 \\
\hline Surgeon & & & & & 1 & 1 \\
\hline Total & 30 & 24 & 42 & 16 & 27 & 139 \\
\hline
\end{tabular}

\section{Defendant gender}

The majority of the defendants was male; $80.6 \%$. For complaints about sexual transgressive behaviour this percentage was $88.9 \%$. The OR that a complaint concerning sexual transgressive behaviour was made against a male versus a female healthcare professional is significantly higher (OR 4.25; 95\% CI 1.7590 to 10.2685 ; $\mathrm{p}=0.0013$ ).

\section{Complainants}

Most complaints were filed by the patient themselves $(\mathrm{n}=66 ; 47.5 \%)$, of which $75.8 \%$ were female. The IGJ filed 41 complaints $(29.5 \%)$, followed by (former) employer of the defendant $(\mathrm{n}=19 ; 13.7 \%)$ and patient relatives $(\mathrm{n}=16 ; 11.5 \%)$. The other complaints were filed by an employee (2), insurance company (1) and friend (1) of the defendant.

\section{Disciplinary court decisions (including substantiated cases)}

Of the 90 disciplinary cases in which the complaint was related to sexually transgressive behaviour, $83.3 \%$ $(\mathrm{n}=75)$ were ruled to be substantiated (5 of which partially). Of the remaining complaints, 13 complaints were declared unfounded and two complainants were inadmissible. Of the 75 justified complaints of sexual misconduct, a measure was imposed in all cases: six formal warnings $(8 \%), 11$ reprimands $(14.7 \%), 10$ denials (partial suspension) (13.3\%), 26 temporary suspensions $(34.7 \%)$ and 22 cancellations of the licence to practice $(29.3 \%)$. Table 2 provides an overview of the decisions broken down into sexual and non-sexual transgressive behaviour.

Of the 49 complaints involving non-sexual transgressive behaviour, approximately half $(26 ; 53.1 \%)$ were ruled to be substantiated. The number of severe disciplinary measures, such as suspension and cancellation of the licence to practice, was lower than for the group of sexually transgressive behaviour. In one case $(2 \%)$ no sanction was imposed, six warnings $(12.2 \%), 6$ reprimands $(12.2 \%)$, one denial (2\%), five suspensions $(10.2 \%)$ and seven cancellations (14.3\%). 
Table 2 Tribunal decisions for sexually and non-sexually transgressive behaviour

\begin{tabular}{lccc}
\hline & \multicolumn{3}{l}{$\begin{array}{l}\text { Sexually transgressive } \\
\text { behaviour }\end{array}$} \\
\cline { 2 - 4 } Decision & 2 & No & Total \\
\hline Inadmissible & 13 & 23 & 2 \\
\hline Unfounded & 5 & 0 & 5 \\
\hline Partially substantiated & 1 & 0 & 1 \\
\hline Warning & 1 & 0 & 1 \\
\hline Reprimand & 2 & 0 & 2 \\
\hline Suspension & 1 & 0 & 1 \\
\hline Cancellation & 70 & 26 & 96 \\
\hline Substantiated & 0 & 1 & 1 \\
\hline No measure & 5 & 6 & 11 \\
\hline Warning & 10 & 6 & 16 \\
\hline Reprimand & 10 & 1 & 11 \\
\hline Denial & 24 & 5 & 29 \\
\hline Suspension & 21 & 7 & 28 \\
\hline Cancellation & 90 & 49 & 139 \\
\hline Total & & & \\
\hline
\end{tabular}

Of the 41 complaints submitted by the IGJ (35 of which involved sexually transgressive behaviour and 6 cases of non-sexual misconduct) $39(95.1 \%)$ resulted in a disciplinary measure, accounting for $39 \%$ of the total of the imposed measures for unacceptable behaviour. Complaints submitted by (former) employers also relatively often resulted in a disciplinary measure; all 19 complaints submitted by (former) employers were upheld and a disciplinary measure was imposed 18 times (including 5 cancellations of licence to practice and 6 (conditional/temporary) suspensions). This percentage of disciplinary measures is considerably lower for complaints submitted by patients. Of the 66 complaints submitted by patients, about half (31) were declared unfounded. One complainant was inadmissible (former employee of the defendant). The other 34 complaints resulted in a disciplinary measure $(51.5 \%)$; 6 cancellations, 12 suspensions, 7 reprimands and 9 warnings.

The OR that a complaint submitted by the healthcare inspection is declared substantiated, compared with a complaint submitted by a patient, is significantly higher (OR 11.32; 95\% CI 2.5796 to 49.6987; $\mathrm{p}=0.0013$ ). For complaints submitted by (former) employers, compared with complaints submitted by patients, the OR was also significantly higher (OR 36.74; $95 \%$ CI 21299 to 633.7194; $\mathrm{p}=0.0131)$.

\section{Sexual transgressive behaviour}

Over the research period, we found 90 cases featuring sexual transgressive behaviour, on average 18 cases per year. These represent $64.7 \%$ of all complaints about transgressive behaviour, with the remaining $35.3 \%$ concerning non-sexual transgressive behaviour. The substantiated cases mean 3.7 imposed measures for sexual transgressive behaviour per 10000 healthcare professionals per 5 years.

\section{DISCUSSION}

This study describes the number and nature of handled disciplinary complaints about transgressive behaviour from registered healthcare professionals in the Netherlands in the 5-year period, 2015-2019. Here, we discuss the main findings and place them in an international context. Set against international literature, a few things stand out, which we will discuss below.

We focus on the vulnerable circumstances of mental healthcare and self-employed physicians (private practice), gender differences and sexual transgressions as specific reasons for disciplinary complaints.

\section{Vulnerable circumstances in mental healthcare}

Despite the fact that in the Netherlands mental healthcare is relatively small compared with the rest of healthcare with $6.5 \%$ of all healthcare professionals working in mental healthcare, half of the number of disciplinary complaints about unacceptable behaviour is originating from this sector. Several possible explanations may exist. First of all, the patient group is often complex, in which part of the patient pathology is actually expressed through interpersonal contact. ${ }^{21}$ In addition, in mental healthcare in general and in psychotherapeutic treatments in particular, there are more frequently long-term treatment contacts; leaving more room for the development of transference and countertransference ${ }^{22-24}$ which carries risks of transgressive behaviour. In addition, the nature of these treatment modalities plays a role, often without the four-eyes principle.

The over-representation of physicians, psychologists and psychotherapists, compared with other healthcare professions, deserves attention. Similar ratios were found in USA, ${ }^{85-27}$ Australian, ${ }^{28}{ }^{29}$ Canadian, ${ }^{9}{ }^{30}$ English $^{31}$ and New Zealand ${ }^{28} 29$ studies. With regard to unacceptable behaviour by psychiatrists/psychotherapists, a review described that awareness, education and supervision can help to prevent unacceptable behaviour, but that ultimately the self-reflective capacity of the care provider should act as a warning system. ${ }^{32}$ However, research shows that such a warning system cannot be taken for granted ${ }^{10} 33$ and that male interns in particular have a different view of this than doctors. ${ }^{34}$ Boundary violating behaviour during medicine study also appears to be predictive of receiving a complaint later in ones career as a doctor. ${ }^{35}$ More attention to this subject therefore seems necessary in undergraduate medical education, postgraduate training and continuing medical education. Additional training could be offered to learn about recent developments in jurisprudence.

\section{Gender differences}

Second, the male:female ratio. Overall, $80.6 \%$ $(\mathrm{n}=112 / 139)$ of the complaints regarding misconduct 
concerned male healthcare professionals. Of the complaints regarding professional (ie, non-sexual) misconduct $65.3 \%$ concerned men $(n=32 / 49)$. Of the sexual misconduct complaints $88.9 \%$ concerned male healthcare professionals $(n=80 / 90)$. Research specifically into the gender of healthcare professionals and (disciplinary complaints about) sexually transgressive behaviour is not available. Previous research ${ }^{8937-39}$ sparsely report specific breakdowns by gender and by nature of the misconduct, however, across all disciplinary complaints, between $60 \%$ and $90 \%$ of the defendants were male. None of these studies reported the nature of the transgressive behaviour. Seen in that light, the question remains to what extent the Dutch situation is comparable to other countries. A meta-analysis of 32 international studies into general (disciplinary) lawsuits against doctors, not specifically about unacceptable behaviour, showed that men were almost two and a half times more likely to be subjected to it than women. ${ }^{40}$ It has been suggested that female doctors have more (personality) characteristics, such as self-awareness and empathy, that would benefit a doctor-patient relationship, ${ }^{29}$ which could lead to fewer complaints. ${ }^{41}$ Naturally, other aspects that are not related to individual healthcare professionals, such as patient population and work environment, also play a role. American research showed that certain patient characteristics (such as female gender and young age) and certain physician characteristics (including male gender, age over 39 years and working solo in a non-academic setting) were associated with sexually transgressive behaviour by the doctor. $^{42}$

\section{Sexual misconduct}

In this study, we found 3.7 imposed measures for sexual transgressive behaviour per 10000 healthcare professionals per 5 years, which seems comparable to US figures $( \pm 9.5$ per 10000 physicians per 10 years) and lower than reports from Canada $( \pm 15.5$ per 10000 doctors per 10 years). Of course the term 'healthcare professionals' contains more disciplines than physicians/doctors, which makes direct comparison difficult. Future research might address these differences, in particular whether the nature of transgressive behaviour differs between countries, or between cadres of healthcare professionals.

\section{Strengths and limitations}

This study is the first to analyse handled disciplinary law cases of transgressive behaviour by Dutch healthcare professionals. This study adds to the existing body of research. Limitations of this study concern the inherent weaknesses in the used website http://tuchtrechtoverheidnl. We have limited ourselves to the number of complaints handled, in contrast to, for example, the number of complaints submitted (the latter complaints are not publicly accessible). In addition, we have limited ourselves to complaints handled by the RDTs: for some of the complaints, this may have led to a different decision on appeal to the Central Disciplinary Court.
Due to the structure of disciplinary law in the Netherlands, complaints are limited to professionals as registered under the BIG. The IGJ recently reported that in 2019 they received 290 reports of sexually transgressive behaviour by care providers, in which 99 cases had been consulted with the police. ${ }^{43}$ This number is lower than the number of disciplinary cases handled in that year (30). A possible explanation for this is that (some) of these reports concerned care providers who do not fall under the BIG and therefore do not fall under the disciplinary law for healthcare, or that a disciplinary complaint has not (yet) been handled or filed for all of these reports. Finally, we have limited ourselves to numerical analysis: no conclusive explanatory insights or hypotheses can be generated with this.

\section{CONCLUSION}

This article describes the first study into jurisprudence of disciplinary cases about transgressive behaviour of healthcare professionals in the Netherlands. We have described the number and type of disciplinary complaints and placed them in the context of the literature. In the period 2015-2019, there were 139 unique disciplinary complaints about transgressive behaviour, an average of 27.8 per year. Of all disciplinary complaints about transgressive behaviour, two-thirds $(64.7 \%)$ concerned sexually transgressive behaviour (18 per year). Most complaints were directed against physicians, followed by nurses, psychologists and physiotherapists. Among the physicians, psychiatrists(/psychotherapists) and general practitioners were most represented. Three quarters of the disciplinary complaints about transgressive behaviour came from an outpatient setting. About half of the complaints originate from mental healthcare. Male healthcare professionals seem over-represented. These findings are relevant to healthcare professionals, health lawyers, professional organisations, employers, educators and policy-makers.

Twitter Frank L Gerritse @FLGerritse and Robbert J Duvivier @robbduv

Contributors FLG and RJD contributed equally in the design of the study, analysis and interpretation of the data. Both authors wrote and critically revised the manuscript.

Funding The authors have not declared a specific grant for this research from any funding agency in the public, commercial or not-for-profit sectors.

Competing interests None declared.

Patient and public involvement Patients and/or the public were not involved in the design, or conduct, or reporting, or dissemination plans of this research.

Patient consent for publication Not applicable.

Ethics approval As this study used publicly available data, no ethical approval was required in accordance with Dutch law.

Provenance and peer review Not commissioned; externally peer reviewed.

Data availability statement Data are available on reasonable request. All data relevant to the study are included in the article. Please contact the corresponding author for access to data.

Open access This is an open access article distributed in accordance with the Creative Commons Attribution Non Commercial (CC BY-NC 4.0) license, which permits others to distribute, remix, adapt, build upon this work non-commercially, and license their derivative works on different terms, provided the original work is 
properly cited, appropriate credit is given, any changes made indicated, and the use is non-commercial. See: http://creativecommons.org/licenses/by-nc/4.0/.

\section{ORCID iDs}

Frank L Gerritse http://orcid.org/0000-0002-5825-050X

Robbert J Duvivier http://orcid.org/0000-0001-8282-1715

\section{REFERENCES}

1 Kao AC, Parsi KP. Content analyses of oaths administered at U.S. medical schools in 2000. Acad Med 2004;79:882-7.

2 Sritharan K, Russell G, Fritz Z, et al. Medical oaths and declarations. BMJ 2001;323:1440-1.

3 Green B. Use of the Hippocratic or other professional oaths in UK medical schools in 2017: practice, perception of benefit and principlism. BMC Res Notes 2017;10:777.

4 Cos $\mathrm{H}$ of. The oath. Loeb class. LiBr. Available: https://www. loebclassics.com/view/hippocrates_cos-oath/1923/pb_LCL147.299. xml;jsessionid=0799C888739E958F399879B4872C5A2B [Accessed 20 Apr 2021].

5 O'Neil A, Sojo V, Fileborn B, et al. The \#MeToo movement: an opportunity in public health? Lancet 2018;391:2587-9.

6 Van Houdenhove E, Van Velthoven J, Messelis E. Seksueel grensoverschrijdend gedrag in de zorg. Politeia; Brussel, 2015. https://lirias.kuleuven.be/1660915

7 Vandecasteele T, Debyser B, Van Hecke A. Grensoverschrijdend gedrag in zorgrelaties : wat betekent het voor patiënten? In: Zorg zonder grenzen, Samenvattingen van Het symposium, 2016. http:// hdl.handle.net/1854/LU-8513589

8 AbuDagga A, Wolfe SM, Carome M, et al. Cross-Sectional analysis of the 1039 U.S. physicians reported to the National practitioner data bank for sexual misconduct, 2003-2013. PLoS One 2016;11:e0147800.

9 Alam A, Klemensberg J, Griesman J, et al. The characteristics of physicians disciplined by professional colleges in Canada. Open Med 2011;5:e166.

10 Cooper I, Jenkins S. Sexual boundaries between physiotherapists and patients are not perceived clearly: an observational study. Aust $J$ Physiother 2008;54:275-9.

11 Bachmann KM, Bossi J, Moggi F, et al. Nurse-patient sexual contact in psychiatric hospitals. Arch Sex Behav 2000;29:335-47.

12 Ministry_of_Health. Healthcare professionals act (wet big) legislation, 2020. Available: https://english.bigregister.nl/registration/procedures/ legislation

13 Bakker JJR. Tuchtrecht onder de wet big. TGVR 2000;24:141-5.

14 Laarman BS, Bouwman RJ, de Veer AJ, et al. How do doctors in the Netherlands perceive the impact of disciplinary procedures and disclosure of disciplinary measures on their professional practice, health and career opportunities? A questionnaire among medical doctors who received a disciplinary measure. BMJ Open 2019;9:e023576.

15 Hout E, Friele R, Legemaate J. [The citizen as plaintiff in disciplinary procedures, lack of complaints possibly due to poor knowledge of the disciplinary system for health care]. Ned Tijdschr Geneeskd 2009;153:A548.

16 Hout FAG, Cuperus-Bosma JM, de Peuter OR. Tuchtrechtspraak voor de gezondheidszorg in Nederland; 1983-2002. Ned Tijdschr Geneeskd 2007;151:881-6.

17 Van der Wal G. Geneeskunde en recht Medische tuchtrechtspraak in Nederland; Een 10-jaarsoverzicht. Ned Tijdschr Geneeskd 1996;140:2640-3.

18 Hout FAG, Kaupmann NL, Alhafaji FY, et al. Tuchtklachten van de Inspectie voor de Gezondheidszorg effectief voor aangeklaagden en beroepsgenoten. Tijds. gezondheids. wetenschappen 2011;89:58-64.

19 Ministerie van Volksgezondheid Welzijn en Sport. Jaarverslag tuchtklachtfunctionarissen, 2019. Available: https://www. rijksoverheid.nl/ministeries/ministerie-van-volksgezondheid-welzijn- en-sport/documenten/rapporten/2020/06/30/jaarverslag-tuchtklachtf unctionarissen-2019

20 BIG-register. Course of big registrations over 5 years, 2021. Available: https://www.bigregister.nl/over-het-big-register/cijfers/ verloop-over-5-jaar [Accessed 8 Sep 2021].

21 Tyrer P, Reed GM, Crawford MJ. Classification, assessment, prevalence, and effect of personality disorder. Lancet 2015;385:717-26.

22 van DF. Overdracht en tegenoverdracht- Een therapeutisch fenomeen vertaald naar alledaagse psychosociale begeleiding. Soest: Nelissen, 2004.

23 de Jonghe F. Overdracht en tegenoverdracht in psychoanalytische psychotherapie. Overdracht en tegenoverdracht Psychoanal Psychother, 1995: 9.

24 Wijts PMH, Kooiman CG, Swaab LF. Transference focused psychotherapy. PSIE 2003;29:83-92.

25 Sansone RA, Sansone LA. Crossing the line: sexual boundary violations by physicians. Psychiatry 2009;6:45.

26 Khaliq AA, Dimassi H, Huang C-Y, et al. Disciplinary action against physicians: who is likely to get disciplined? Am J Med 2005;118:773-7.

27 Morrison J, Morrison T. Psychiatrists disciplined by a state medical board. Am J Psychiatry 2001;158:474-8.

28 Elkin K, Spittal MJ, Elkin D, et al. Removal of doctors from practice for professional misconduct in Australia and New Zealand. BMJ Qual Saf 2012;21:1027-33.

29 Elkin KJ, Spittal MJ, Elkin DJ, et al. Doctors disciplined for professional misconduct in Australia and New Zealand, 2000-2009. Med J Aust 2011;194:452-6.

30 Alam A, Kurdyak P, Klemensberg J, et al. The characteristics of psychiatrists disciplined by professional colleges in Canada. PLOS One 2012;7:e50558.

31 Stacey M. The general medical Council and professional selfregulation. Regul Dr 2000:28-39.

32 Jousset N, Gaudin A, Penneau M, et al. Practitioner sex abuse: occurrence, prevention and disciplinary sanction. Med Sci Law 2008;48:203-10.

33 Baca M. Sexual boundaries: are they common sense? The Journal for Nurse Practitioners 2009;5:500-5.

34 Dekker H, Snoek JW, Schönrock-Adema J, et al. Medical students' and teachers' perceptions of sexual misconduct in the studentteacher relationship. Perspect Med Educ 2013;2:276-89.

35 Papadakis MA, Hodgson CS, Teherani A, et al. Unprofessional behavior in medical school is associated with subsequent disciplinary action by a state Medical board. Acad Med 2004;79:244-9.

36 Papadakis MA, Teherani A, Banach MA, et al. Disciplinary action by medical boards and prior behavior in medical school. N Engl J Med 2005;353:2673-82.

37 AbuDagga A, Wolfe SM, Carome M, et al. Crossing the line: sexual misconduct by nurses reported to the National practitioner data bank. Public Health Nurs 2019;36:109-17.

38 Enbom JA, Parshley P, Kollath J. A follow-up evaluation of sexual misconduct complaints: the Oregon board of medical examiners, 1998 through 2002. Am J Obstet Gynecol 2004;190:1642-53.

39 Enbom JA, Thomas CD. Evaluation of sexual misconduct complaints: the Oregon board of medical examiners, 1991 to 1995. Am J Obstet Gynecol 1997;176:1340-8.

40 Unwin $\mathrm{E}$, Woolf $\mathrm{K}$, Wadlow $\mathrm{C}$, et al. Sex differences in medico-legal action against doctors: a systematic review and meta-analysis. BMC Med 2015;13:172.

41 Firth-Cozens J. Doctors with difficulties: why so few women? Postgrad Med J 2008;84:318-20.

42 DuBois JM, Walsh HA, Chibnall JT, et al. Sexual violation of patients by physicians: a mixed-methods, exploratory analysis of 101 cases. Sex Abuse 2019;31:503-23.

43 Skipr. Igj verdenkt 100 zorgverleners van seksueel misbruik. Skipr, 2020. Available: https://www.skipr.nl/uitgelicht/igj-verdenkt-100zorgverleners-van-seksueel-misbruik/ 